\title{
Uji Pengaruh Energi Rapid Impact Compaction terhadap Tingkat Kepadatan Tanah Timbunan
}

\author{
Rokhman*, Lawalenna Samang, Tri Harianto \\ Departemen Teknik Sipil, Faakultas Teknik, Universitas Hasanuddin \\ Jl. Poros Malino km.6, Bontomarannu, Kabupaten Gowa, Sulawesi Selatan 92171 \\ *Email: rokhmansoq@yahoo.co.id
}

DOI: 10.25042/jpe.052019.12

\begin{abstract}
Abstrak
Penelitian ini dimaksudkan untuk menganalisis pengaruh energi pemadatan metode Rapid Impact Compaction (RIC) terhadap karakteristik pemadatan pada tanah timbunan. Metode yang digunakan adalah model alat RIC hasil pengembangan di Laboratorium Mekanika Tanah Universitas Hasunuddin dimana alat ini di kendalikan secara elektro-mekanis. Proses pemadatan dilakukan dengan memvariasikan jumlah tumbukan untuk variasi energi pemadatan. Dimana berat beban penumbuk $70 \mathrm{~kg}$ dan tinggi jatuh $15 \mathrm{~cm}$. Untuk uji elemen menggunakan mould berdiameter $15 \mathrm{~cm}$ dan tinggi $25 \mathrm{~cm}$ sedangkan uji model mengunakan bak uji berdiameter $80 \mathrm{~cm}$ dan tinggi $120 \mathrm{~cm}$. Untuk menguji tingkat kepadatan menggunakan DCP Test, CBR Test dan Sandcone Test. Hasil pengujian mendapatkan adanya pengaruh energi pemadatan terhadap nilai CBR dan berat isi kering tanah. Hubungan antara perbandingan energi pemadatan RIC terhadap energi pemadatan standard proctor memenuhi persamaan $\Upsilon_{\mathrm{d} \text { RIC }}=0,0915$ (ESP) $+1,046$. Dari grafik didapatkan titik perpotongan yang merupakan titik optimum energi RIC untuk mendapatkan kepadatan sesuai energi pemadatan proctor. Dalam pengujian ini didapatkan titik optimum energinya sebesar 2.01 ESP terhadap pemadatan standard proctor dan 3.32 ESP terhadap modified proctor. Pada pengujian pemadatan RIC model pada kumulatif jumlah tumbukan sebanyak 90 kali tanah tidak mengalami penurunan. Evaluasi kinerja hasil pemadatan RIC didapat nilai Relatif Compaction (Rc) sebesar $95 \%$.
\end{abstract}

\begin{abstract}
Influence Rapid Impact Compation to the Level of Soil Density. This research is intended to analyze the effect of compaction energy method of Rapid Impact Compaction (RIC) on the compaction characteristics of embankment soil. The method used is the RIC tool model developed from the Hasunuddin University Soil Mechanics Laboratory where this tool is controlled electro-mechanically. The compaction process is carried out by varying the number of collisions for the variation of compaction energy. Where the pounder weight is $70 \mathrm{~kg}$ and the height falls $15 \mathrm{~cm}$. To test the elements using molds with a diameter of $15 \mathrm{~cm}$ and a height of $25 \mathrm{~cm}$, to test the density level using the DCP Test, CBR Test and Sandcone Test. The test results get the effect of compaction energy on the CBR value and the dry weight content of the soil. The relationship between the comparison of RIC compaction energy with proctor standard compaction energy meets the equation $Y \mathrm{~d}$ RIC $=0.0915$ $(E S P)+1.046$. From the graph, the point of intersection which is the optimum point of RIC energy to get the density according to the proctor compaction energy. In this test, the optimum energy point of 2.01 ESP was obtained against compaction of the standard proctor and 3.32 ESP of the modified proctor. In the compaction testing of the RIC model, the cumulative number of collisions is 90 times that the soil does not decrease. Evaluation of the performance of the RIC compaction results obtained Relative Compaction (Rc) of $95 \%$.
\end{abstract}

Kata Kunci: Berat isi kering, kepadatan tanah, Rapid impact compaction

\section{Pendahuluan}

Salah satu metode pemadatan dinamis lapisan timbunan tebal yang dikenal saat ini diantaranya adalah Rapid Impact Compaction. Metode ini adalah pemadatan tanah secara dinamis dengan konsep Low Energi Dynamic Compaction. Peralatan utama Rapid Impact Compaction berupa massa penumbuk yang di jatuhkan dari ketinggian tertentu. Hal yang membedakan metode ini dengan Dynamic Compaction adalah penggunaan massa penumbuk yang lebih ringan, tinggi jatuh yang lebih rendah namun dengan frekuensi tumbukan yang lebih tinggi, sehingga total kumulatif energi yang dihasilkan pada metode RIC lebih besar daripada metode Dynamic Compaction (DC) dalam satuan waktu yang sama $[1,2]$. 
Dilaboratorium pengaruh usaha pemadatan umumnya di uji menggunakan standard proctor maupun modified proctor dengan mengacu pada kurva hasil pemadatan. Telah umum di ketahui bahwa jika energi usaha pemadatan persatuan volume tanah berubah maka kecenderungannya adalah kurva pemadatan juga akan berubah dengan meningkatnya usaha pemadatan dengan parameter utamanya adalah berat volume kering dan kadar air [3].

Menurut Proctor, ada hubungan yang pasti antara kadar air dan berat volume kering yang dipadatkan sebagaimana persamaan (1) dalam hal ini $\mathrm{w}(\%)$ persentase kadar air; $\gamma=$ berat volume tanah. Untuk berbagai jenis tanah pada umumnya terdapat suatu nilai kadar air optimum tertentu untuk mencapai berat volume kering maksimumnya, kepadatan kering pada kadar air optimum didefinisikan sebagai kepadatan kering maksimum. Berdasarkan Persamaan (1) setiap peningkatan kadar air yang melebihi kadar air optimum cenderung mengurangi kepadatan kering [3].

$$
\gamma d=\frac{\gamma}{1+\frac{w(\%)}{100}}
$$

Selain kadar air dan jenis tanah, faktor penting lainnya yang mempengaruhi pemadatan adalah energi per satuan volume. Energi pemadatan per satuan volume yang digunakan untuk uji Proctor dintentukan oleh jumlah tumbukan perlapisan $(\mathrm{N})$; jumlah lapisan per mould (l); berat penumbuk (W) dan tinggi jatuh penumbuk (h) persatuan volume mould (V) yang dapat dinyatakan dengan Persamaan (2) [3].

$$
E=\frac{N \cdot l \cdot W \cdot h}{V}
$$

Meningkatkan usaha pemadatan akan meningkatkan kepadatan maksimum namun akan mengurangi kadar air optimum. Kurva pemadatan secara umum memperlihatkan bahwa rasio void udara tetap sama pada kepadatan maksimum, sehingga pada kadar air yang tinggi, hanya ada sedikit pertambahan kepadatan yang diperoleh dengan meningkatkan usaha pemadatan. Tanah lempung memiliki kandungan air optimum yang jauh lebih tinggi, akibatnya menurunkan kepadatan kering maksimum. Efek meningkatkan upaya pemadatan juga jauh lebih besar dalam kasus tanah lempung [4].

Peralatan Rapid Impact Compaction, RIC terdiri atas tiga komponen utama yaitu alas penumbuk; alur penumbuk, dan penumbuk [5]. Pada metode pemadatan rapid impact compaction, penumbuk dijatuhkan secara tetap pada alas penumbuk yang ditempatkan diatas permukaan tanah dengan frekuensi tumbukan antara 3060/menit sebagai ciri metode rapid compaction, [6]. Parameter energi pemadatan metode, RIC ditentukan oleh berat penumbuk (compactor); berat dan luas geometri landasan penumbuk (anvil); frekuensi tumbukan dan kumulatif total tumbukan dalam satu siklus pemadatan pada titik tumbukan yang sama.

Peralatan Rapid Impact Compaction, RIC terdiri atas tiga komponen utama yaitu alas penumbuk; alur penumbuk dan penumbuk. Peralatan penumbuk ditautkankan ke hydraulic excavator sebagai perangkat penopang mekanik yang dapat mengatur frekuensi tumbukan antara 40-60/menit sebagai ciri metode rapid compaction, [7]. Pada metode dynamic compaction, maka total energi $\mathrm{E}$ tumbukan per luas bidang kontak alas penumbuk $\left(\mathrm{kJ} / \mathrm{m}^{2}\right)$, dihitung dengan Persamaan (3), dalam hal ini $\mathrm{E}$ adalah kumulatif total energi yang dikenakan kN.m (kJ), A adalah luas bidang tumbuk dari alas penumbuk $\left(\mathrm{m}^{2}\right)$, dan $\mathrm{N}$ adalah jumlah tumbukan [6].

$$
E=\frac{1}{2}\left(W_{H}+W_{F}\right) \cdot V_{F}^{2}\left(\frac{N}{A}\right)
$$

\section{Metode Penelitian}

\subsection{Material}

Contoh tanah yang digunakan masuk klasifikasi sebagai tanah lanau plastisitas tinggi (MH) sesuai dengan sistem klasifikasi tanah USCS. Adapun sifat fisik contoh tanah yang di gunakan dalm penelitian ini dirangkum dalam Tabel 1. 
Tabel 1. Sifat fisik material tanah pengujian

\begin{tabular}{cc}
\hline Sifat fisik & Nilai \\
\hline Berat Volume Basah, $\gamma$ & $1,03 \mathrm{gr} / \mathrm{cm}^{3}$ \\
Kadar air rata-rata, $\omega$ & $38,36 \%$ \\
Spesific gravity, G & 2,73 \\
Berat isi & $1.03 \mathrm{gr} / \mathrm{cm}^{3}$ \\
Batas Cair, $L L$ & $55,89 \%$ \\
Batas Plastis, $P L$ & $47,48 \%$ \\
Indeks Plastisitas, $I P$ & $8,41 \%$ \\
\hline
\end{tabular}

\subsection{Peralatan Pengujian}

Dalam penelitian ini digunakan peralatan pengujian repetead load impak berbasis air pneumatik pressure sebagaimana diperlihatkan dalam Gambar 1. Adapun komponen utama peralatan tersebut terdiri dari kompressor udara; piston double acting; valve selenoid, panel kendali kontroller, massa penumbuk dan landasan tumbukan, alat ini sebagaimana di uraikan secara rinci dalam [7].

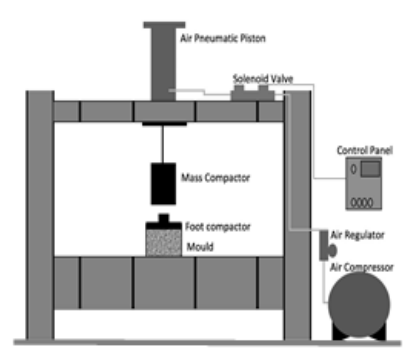

(a)

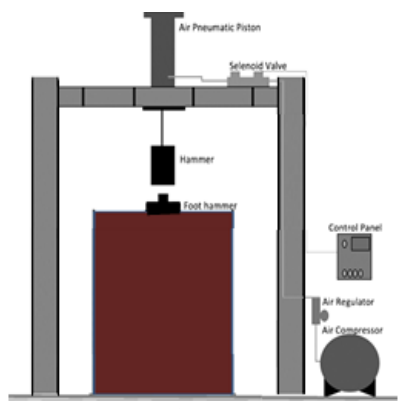

(b)
Gambar 1. Set-up peralatan: a. uji RIC elemen; b. Uji RIC Model

Digunakan massa penumbuk yang terbuat dari material baja seberat $70 \mathrm{~kg}$ yang ditautkan pada ujung batang piston yang berfungsi sebagai kait beban. Beban tersebut dapat di jatuhkan pada ketinggian sesuai dengan setting ketinggian pada panel kontrol. Untuk pengujian di gunakan mould dengan ukuran diameter dalam $15 \mathrm{~cm}$, tigggi $25 \mathrm{~cm}$, volume cetakan $0,0044 \mathrm{~m}$. Untuk proses pemadatan, mold di lengkapi dengan alas pemadat yang ukurannya disesuaikan dengan diameter cetakan. Alas tumbukan terbuat dari pelat baja diameter $15 \mathrm{~cm}$.

\subsection{Rancangan Pengujian}

- Persiapan Sampel Tanah.

Tanah dalam tabung silinder untuk kompaksi diperoleh dari sampel yang dibentuk kembali. Untuk menyiapkan sampel ini, sejumlah berat tanah yang sebelumnya telah kering oven dicampur dengan sejumlah air mendapatkan kadar air yang sesuai dengan target kadar air rencana pengujian yaitu 15\%-35\%, dimana rentang kadar air ini sebelumnya telah di uji menggunakan pemadatan proctor. Tanah yang telah di atur kadar air diambil seberat 4,6 kg dan di isikan dalam tabung silinder tanpa dilakukan pemadatan dengan mengontrol kepadatan gemburnya sebesar $1,03 \mathrm{gr} / \mathrm{cm}^{3}$.

- Proses Pemadatan RIC elemen

Upaya pemadatan dengan Rapid Impact Compaction dilakukan pada mould berukuran diameter $15 \mathrm{~cm}$ dan tinggi $25 \mathrm{~cm}$. Untuk mengetahui pencapaian nilai kepadatan dilakukan uji DCP dan CBR. Pemadatan dilakukan menggunakan berbagai tingkat energi dengan menerapkan berbagai usaha impak yang digunakan. Penumbuk yang berbentuk persegi dengan berat $70 \mathrm{~kg}$ dijatuhkan dari ketinggian $15 \mathrm{~cm}$ dengan variasi jumlah pukulan 5, 15, 25 dan $35 \mathrm{~m}$ lihat Gambar 1(a).

- Proses Pemadatan RIC Uji Model

Upaya pemadatan dengan Rapid Impact Compaction pada bak uji silinder dengan ukuran diameter $80 \mathrm{~cm}$ dan tinggi $120 \mathrm{~cm}$. yang diisi tanah sampai penuh sebanyak $621 \mathrm{~kg}$. Pemadatan dilakukan menggunakan peralatan RIC dengan berat penumbuk $70 \mathrm{~kg}$, tinggi jatuh $15 \mathrm{~cm}$ dna geometri alas tumbukan berdiameter $30 \mathrm{~cm}$. Proses pemadatan dilakukan sampai dengan tanah tidak mengalami penurunan lagi. Untuk mengetahui pencapaian nilai kepadatan dilakukan uji CBR, uji DCP dan uji Sandcone lihat Gambar 1(b). 


\section{Hasil dan Pembahasan}

\subsection{Energy Proctor Compaction dan Rapid Impact Compaction}

Hasil perhitungan Energy Proctor Compaction dan Rapid Impact Compaction serta rasio perbandingannya dapat dilihat pada Tabel berikut ini:

Tabel 2. Energy Proctor Compaction dan Rapid Impact Compaction serta rasio perbandingannya

\begin{tabular}{ccccc}
\hline $\begin{array}{c}\text { Type } \\
\text { Pemadatan }\end{array}$ & $\begin{array}{c}\text { Berat } \\
\text { Penumbuk } \\
(\mathbf{k g})\end{array}$ & $\begin{array}{c}\text { Jumlah } \\
\text { Tumbukan } \\
\text { Per Lapis }\end{array}$ & $\begin{array}{c}\text { Energi } \\
\text { Pemadatan } \\
\left(\mathbf{k J} / \mathbf{m}^{3}\right)\end{array}$ & $\begin{array}{c}\text { Rasio } \\
\text { Energi } \\
\text { Standar }\end{array}$ \\
\hline $\begin{array}{c}\text { Standard } \\
\text { Proctor }\end{array}$ & 2,5 & 25 & 592 & 1,00 \\
$\begin{array}{c}\text { Modified } \\
\text { Proctor }\end{array}$ & 4,54 & 25 & 2695 & 4,54 \\
RIC-01 & 70 & 5 & 117 & 0,20 \\
RIC-02 & 70 & 15 & 351 & 0,59 \\
RIC-03 & 70 & 25 & 585 & 0,98 \\
RIC-04 & 70 & 35 & 819 & 1,38 \\
\hline
\end{tabular}

Energy pemadatan baik metode standard proctor maupun modified di dasarkan pada usaha pemadatan yang dilakukan dalam sebuah mould pemadatan berdiamater $101.6 \mathrm{~mm}$ dan tinggi $116,43 \mathrm{~mm}$ yang memiliki volume $944 \mathrm{~cm}^{3}$. Pada pengujian standard proctor besarnya energi pemadatan adalah $592 \mathrm{~kJ} / \mathrm{m}^{3}$, sementara untuk modified proctor adalah $2.695 \mathrm{~kJ} / \mathrm{m}^{3}$. Sementara untuk model Rapid Impact Compaction besarnya didapatkan dengan memvariasikan jumlah tumbukan 5 kali, 15 kali, 25 kali dan 35 kali dengan berat beban penumbuk yang digunakan sebesar 70 $\mathrm{kg}$, tinggi jatuh $15 \mathrm{~cm}$ dan 1 lapis tanah.

Semua proses pemadatan dilakukan hanya menggunakan 1 lapisan pada mould berdiameter $15 \mathrm{~cm}$ dan tinggi $25 \mathrm{~cm}$ dengan volume $0.0044 \mathrm{~m}^{3}$. Sehingga dari proses pemadatan RIC ini besarnya energi usaha pemadatan bervariasi antara 111 $\mathrm{kJ} / \mathrm{m}^{3}$ untuk yang terkecil dan $1.365 \mathrm{~kJ} / \mathrm{m}^{3}$ untuk energi yang terbesar atau jika bandingkan terhadap energi standard proctor bervariasi antara 0,20-1.38 kali.
3.2. Kepadatan Kering dan Kadar Air Optimum pada Tingkat Energi Berbeda

Untuk menjelaskan hubungan variabel kepadatan kering, kadar air optimum pemadatan dan tingkat energi dari usaha pemadatan, maka dilakukan pengamatan dengan hubungan ketiga variabel tersebut, dalam hal ini hubungan tersebut dinyatakan sebagai perbandingan terhadap energi metode standard proctor yaitu $592 \mathrm{~kJ} / \mathrm{m}^{3}$ terhadap perubahan kadar air setiap mould pemadatan sesuai besarnya energi Rapid Impact Compaction yang diberikan lihat Gambar 2.

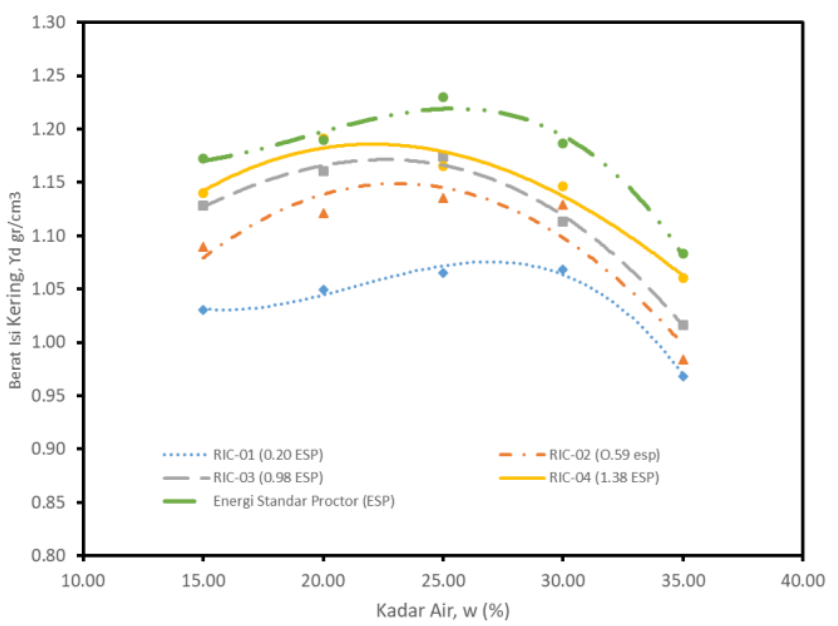

Gambar 2. Hubungan antara energi RIC dan kadar air terhadap berat isi kering ( $\mathrm{Cd})$

Kecenderungan berat isi kering dipengaruhi oleh tingkat energi usaha pemadatan dan kadar air seperti yang terlihat pada Gambar 2. Terlihat bahwa setiap tingkat energi yang diberikan akan menghasilkan kadar air optimum untuk menghasilkan berat isi kering tanah maksimum. Dimana hasilnya memperlihatkan bahwa penambahan energi cenderung mengurangi besarnya nilai kadar air optimum. Untuk energi terbesar pada RIC ini kadar air optimum didapat $20 \%$. Bila di bandingkan hasil pemadatan standard proctor maka berat isi kering yang dihasilkan masih dibawah standard proctor. Untuk mencapainya tentunya harus menaikan energi RIC menyamai bahkan lebih dari energi standard proctor. 
3.3. Hubungan Energi Pemadatan RIC dan Energi Pemadatan Proctor terhadap Berat Isi Kering

Untuk energi yang sama dengan standard proctor $\left(1.00 \mathrm{ESP}=592 \mathrm{~kJ} / \mathrm{m}^{3}\right)$ dihasilkan berat isi kering sebesar $1.14 \mathrm{gr} / \mathrm{cm}^{3}$ atau sebesar $92.68 \%$ terhadap berat isi kering hasil pemadatan standard proctor $\left(1.23 \mathrm{gr} / \mathrm{cm}^{3}\right)$. Agar berat isi kering hasil pemadatan RIC sama dengan berat isi kering tanah standard proctor maka energi RIC harus ditingkatkan sampai dengan 2.01 ESP atau sebesar $1190 \mathrm{~kJ} / \mathrm{m}^{3}$ lihat Gambar 3.

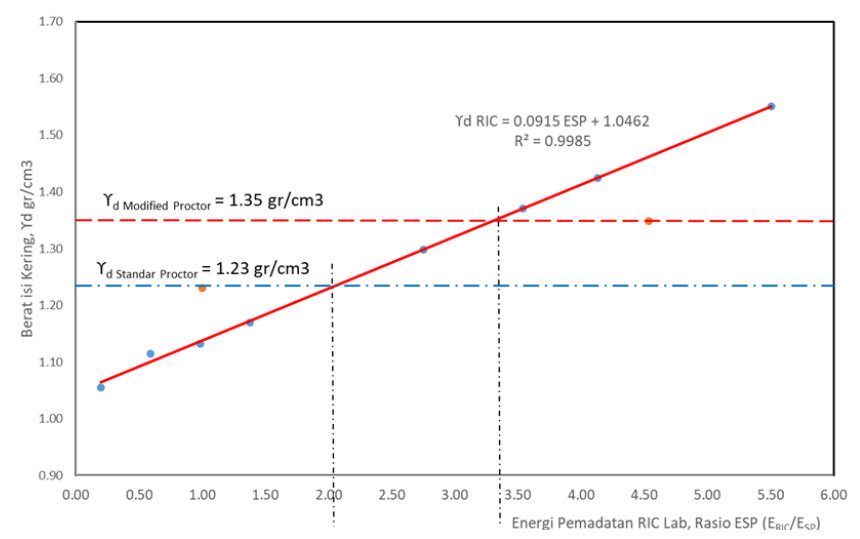

Gambar 3. Hubungan antara energi pemadatan RIC, standard proctor dan modified proctor terhadap berat kering

Dari Gambar 3 diperoleh persamaan berat isi kering tanah hasil pemadatan RIC yaitu :

$$
\Upsilon \mathrm{d}_{\mathrm{RIC}}=0.0915 \mathrm{ESP}+1.0462
$$

dimana :

$$
\begin{aligned}
\mathrm{rd}_{\mathrm{RIC}}= & \text { berat isi kering tanah hasil } \\
& \text { pemadatan Rapid Impact } \\
& \text { Compaction (RIC) } \\
\mathrm{ESP}= & \text { rasio perbandingan antara Energi } \\
& \text { RIC terhadap Energi Standard } \\
& \text { Proctor }\left(\mathrm{E}_{\mathrm{RIC}} / \mathrm{E}_{\mathrm{SP}}\right)
\end{aligned}
$$

Kadar air optimum untuk mendapatkan berat isi kering maksimum untuk energi pemadatan standard proctor adalah sebesar $25 \%$ Sedangkan kadar air optimum untuk mendapatkan berat isi kering maksimum pada pemadatan RIC adalah sebesar $20 \%$ sesuai hasil pengujian pada sejumlah tingkat energi yang berbeda.
Hubungan antara garis berat isi kering hasil pemadatan RIC ( $\left(\mathrm{d}_{\mathrm{RIC}}\right)$ dan berat isi kering hasil pemadatan standard proctor $\left(\Upsilon \mathrm{d}_{\text {Standard }}\right.$ Proctor $)$ terjadi perpotongan di titik $2.01 \mathrm{ESP}$, artinya dengan energi RIC dinaikan sampai dengan 2.01 kali energi Standard Proctor $\left(2.01 \times 592 \mathrm{~kJ} / \mathrm{m}^{3}=\right.$ $1190 \mathrm{~kJ} / \mathrm{m}^{3}$ ) maka berat isi kering yang dihasilkan bisa mencapai $1.23 \mathrm{gr} / \mathrm{cm}^{3}$ sama dengan berat isi kering hasil pemadatan standard proctor lihat Gambar 3. Untuk menghasilkan energi sebesari $1190 \mathrm{~kJ} / \mathrm{m}^{3}$ bila menggunakan alat RIC dengan berat penumbuk $70 \mathrm{~kg}$, tinggi jatuh $15 \mathrm{~cm}$ dan diameter alas tumbukan $15 \mathrm{~cm}$ maka dibutuhkan jumlah tumbukan sebanyak 51 kali.

Hubungan antara garis berat isi kering hasil pemadatan RIC ( $\Upsilon \mathrm{d}_{\mathrm{RIC}}$ ) dan berat isi kering hasil pemadatan Modified Proctor ( $\left(\mathrm{d}_{\text {Modified }}\right.$ Proctor $)$ terjadi perpotongan di titik 3.32 ESP, artinya dengan energi RIC dinaikan sampai dengan 3.32 kali energi Standard Proctor $\left(3.32 \times 592 \mathrm{~kJ} / \mathrm{m}^{3}=\right.$ $1965 \mathrm{~kJ} / \mathrm{m}^{3}$ ) maka berat isi kering yang dihasilkan bisa mencapai $1.35 \mathrm{gr} / \mathrm{cm}^{3}$ sama dengan berat isi kering hasil pemadatan Modified Proctor lihat Gambar 3. Untuk menghasilkan energi sebesari $1965 \mathrm{~kJ} / \mathrm{m}^{3}$ bila menggunakan alat RIC dengan berat penumbuk $70 \mathrm{~kg}$, tinggi jatuh $15 \mathrm{~cm}$ dan diameter alas tumbukan $15 \mathrm{~cm}$ maka dibutuhkan jumlah tumbukan sebanyak 85 kali.

Titik perpotongan garis hubungan antara berat isi kering hasil pemadatan RIC dan Standard Proctor maupun Modified Proctor adalah sebagai acuan untuk mendapatkan energi optimum agar hasil pemadatannya (berat isi kering tanah) yang diperoleh sama dengan kepadatan tanah hasil pemadatan Standard Proctor maupun Modified Proctor.

3.4. Hubungan antara Jumlah Tumbukan (Energi Pemadatan RIC Uji Model) terhadap Penurunan

Hasil pemadatan RIC uji model dapat diketahui bahwa pada awal penumbukan terjadi penurunan yang cukup dalam. Namun pada penumbukan selanjutnya penurunannya berkurang dan akhirnya pada kumulatif jumlah pukulan 90 kali tanah tidak mengalami penurunan lagi. Hal ini sejalan dengan 
teori yang mengatakan bahwa salah satu syarat dihentikan penumbukan pada pemadatan RIC salah satunya adalah bila kumulatif jumlah tumbukkan sudah mencapai 90 kali.

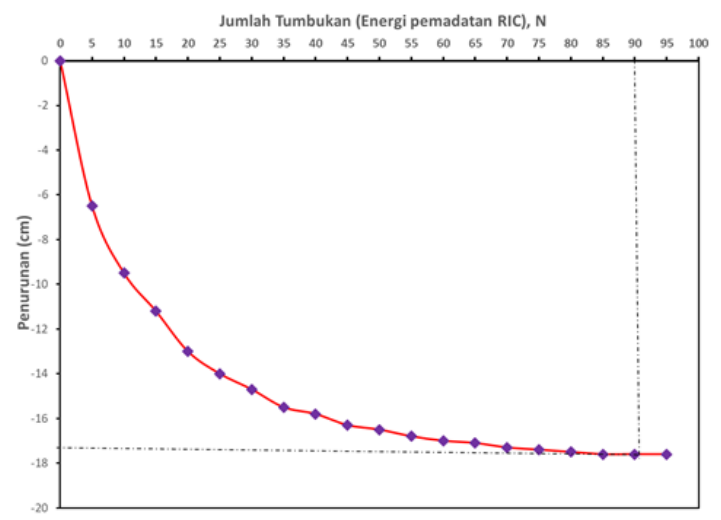

Gambar 4. Hubungan antara Nilai CBR dan kedalaman tanah

3.5. Evaluasi kinerja pemadatan RIC dengan Analisa Relatif Compaction, $\mathrm{R}_{\mathrm{C}}$

Untuk mengevaluasi hasil pemadatan RIC di lapangan maka dilakukan uji model. Pengujian ini dilakukan pada bak uji berbentuk silinder dengan ukuran diameter $80 \mathrm{~cm}$ dan tinggi $120 \mathrm{~cm}$. Seingga volume drum tersebut adalah $0,603 \mathrm{~m}^{3}$ kemudian diisi tanah dengan berat isi $1.03 \mathrm{gr} / \mathrm{cm}^{3}$ sampai penuh atau sebanyak $621 \mathrm{~kg}$. Berat penumbuk Rapid Impact Compaction yang digunakan adalah $70 \mathrm{~kg}$ dengan tinggi jatuh $15 \mathrm{~cm}$ dan diameter alas $30 \mathrm{~cm}$ serta jumlah tumbukan sebanyak 90 kali. Setelah proses pemadatan selesai maka dilakukan pengujian tingkat kepadatan menggunakan Sandcone test untuk mendapatkan berat isi kering tanah ( $\Upsilon \mathrm{d})$ dan juga dilakukan pengujian Dynamic Cone Penetrometer (DCP) Test untuk mendapatkan nilai CBR lapangan.

Untuk kriteria kinerja hasil pemadatan tersebut diukur dengan nilai Relatif Compaction $\left(\mathrm{R}_{\mathrm{c}}\right)$ yaitu membandingkan hasil pencapaian kepadatan kering hasil pemadata RIC terhadap kepadatan kering hasil pemadatan standard proctor, sesuai Persamaan (5) yang dinyatakan dalam prosentase. Nilai ini menyatakan pencapaian kepadatan tanah hasil pemadatan RIC terhadap kepadatan tanah hail pemadatan standard proctor. Dari hasil pengujian pemadatan RIC pada uji model dengan sandcone test maka diperoleh berat isi kering $(\Upsilon \mathrm{d})=1.174$ $\mathrm{gr} / \mathrm{cm}^{3}$. Sehingga nilai Relatif Compaction $\left(\mathrm{R}_{\mathrm{c}}\right)$ dapat diperoleh sebesar $95.46 \%$.

$$
\mathrm{Rc}=\frac{\gamma \mathrm{d} \text { RIC Model }}{\gamma \mathrm{d} \text { Standar Proctor }}
$$

Dengan demikian dari hasil pengujian ini dapat diketahui bahwa pemadatan RIC dapat menghasilkan kinerja pemadatan yang baik, sehingga pemadatan Rapid Impact Compation (RIC) dapat diterapkan di lapangan.

\section{Kesimpulan}

Dari hasil penelitian ini dapat diambil kesimpulan sebagai berikut:

a. Adanya hubungan antara besarnya energi pemadatan Rapid Impact Compaction (RIC) dan kadar air terhadap besarnya berat isi kering tanah. Semakin besar energi pemadatan maka berat isi kering tanah juga akan meningkat, yang dibarengi dengan kadar optimum kecenderungannya semakin berkurang.

b. Besarnya energi pemadatan Rapid Impact Compaction (RIC) mempengaruhi karateristik pemadatan tanah yaitu berat isi kering. Semakin besar energi pemadatan RIC kecenderungannya akan menghasilkan berat isi kering tanah yang lebih besar.

c. Besarnya energi pemadatan Rapid Impact Compaction (RIC) berdasarkan kumulatif jumlah tumbukan berpengaruh terhadap penurunan tanah. Penurunan tanah awalnya cukup besar tetapi lama kelamaan berkurang dan sampai tidak terjadi penurunan lagi. Penurunan tidak terjadi pada jumlah kumulatif pukulan mencapai 90 kali. Artinya pemadatan RIC dapat dihentikan jika kumulati jumlah tumbukan sudah mencapai 90 kali.

d. Untuk mengevaluasi kinerja pemadatan Rapid Impact Compaction (RIC) di lapangan maka dapat digunakan Analisa Relatif Compaction yaitu perbandingan antara berat isi kering hasil pemadatan RIC terhadap berat isi kering hasil standard proctor. Dari hasil pengujian didapat nilai Rc sebesar 95\% ini berarti pemadatan RIC dapat digunakan di lapangan. 


\section{Referensi}

[1] P. J. Becker (2011) "Assessment of rapid impact compaction for transportation infrastructure applications" Graduate Theses and Dissertations. Paper 10261, Iowa State University.

[2] M. M. Mohammed, H. Roslan, and S. Firas (2013), "Assessment of rapid impact compaction in ground improvement from in-situ testing," Journal of Central South University, vol. 20, pp. 786-790.

[3] B. M. Das, (2010). Principles of Geotechnical Engineering, 7 th. Cengage Learning 200 First Stamford Place, Suite 400 Stamford, CT 06902 USA.

[4] C. Rajasekhar, A. Naga Sai baba, and M. Kameswara Rao, (2016) "To Develop a Correlation Between CBR and Dynamic Cone Penetration Value," Int. J. Technol. Res. Eng., vol. 4, no. 1, pp. 11-16.

[5] B. Arifin, L. Samang, T. Harianto, and A. B. Muhiddin, (2017) "Pengembangan Alat Uji Pneumatic Rapid Impact Compaction," Prosiding Konferensi Nasional Teknik Sipil 11, Universitas Tarumanagara, Jakarta, pp. 75-80.

[6] F. Falkner, C. Adam, I. Paulmichl, D. Adam, and J. Fürpass, (2010) "Rapid Impact Compaction for MiddleDeep Improvement of the Ground - Numerical and Experimental Investigations," From Res. to Des. Eur. Pract., no. June, pp. 2-11.

[7] D. Adam and I. Paulmichl, (2007) "Rapid Impact Compactor - An Innovative Dynamic Compaction Device for Soil Improvement," in Improvement of Soil Properties, pp. 183-193. 